\title{
Artificial radionuclides in fish fauna of the Yenisei River in the vicinity of the Mining-and-Chemical Combine (Siberia, Russia)
}

\author{
T. Zotina, E. Trofimova and A. Bolsunovsky \\ Institute of Biophysics SB RAS, Akademgorodok, 660036 Krasnoyarsk, Russia, \\ e-mail: $t$ zotina@ibp.ru
}

\begin{abstract}
Activities of radionuclides were measured in five species of fish (grayling, dace, crucian carp, pike, cod) sampled in the Yenisei River (Siberia, Russia) in the vicinity of the Mining-and-Chemical Combine (ROSATOM) from 2007 to 2010, with a gamma-spectrometer (Canberra, USA). The analyses of samples of organs and tissues of fish species revealed artificial $\left({ }^{46} \mathrm{Sc},{ }^{51} \mathrm{Cr},{ }^{54} \mathrm{Mn},{ }^{58,60} \mathrm{Co},{ }^{59} \mathrm{Fe},{ }^{65} \mathrm{Zn},{ }^{85} \mathrm{Sr}\right.$, $\left.{ }^{99} \mathrm{Mo},{ }^{103,106} \mathrm{Ru},{ }^{137} \mathrm{Cs},{ }^{141,144} \mathrm{Ce}\right)$ and natural $\left({ }^{7} \mathrm{Be},{ }^{40} \mathrm{~K}\right)$ radionuclides in fish organs and tissues, including edible ones. The major percent (up to $80 \%$ ) of ${ }^{137} \mathrm{Cs}$ and ${ }^{40} \mathrm{~K}$ activity occurred in muscles of fish species, which also contained considerable percentages of ${ }^{60} \mathrm{Co}$ (up to $70 \%$ ) and ${ }^{65} \mathrm{Zn}$ (up to 20\%). Seasonal changes in the intake of artificial radionuclides by zoobenthos-feeding fish species (grayling and dace) were recorded and they were followed by an activity concentration increase in internal organs. The dramatic increase in radionuclide intake by grayling coincided with the change of diet source. Hence, the feeding behavior of fish can change the fluxes of artificial radionuclides in the Yenisei River. The most effective diet transfer of a radionuclide from gammarus to grayling (muscles and total body) was recorded for ${ }^{40} \mathrm{~K}(1.3)$ and much less effective for artificial nuclides.
\end{abstract}

\section{INTRODUCTION}

The Yenisei River is contaminated with artificial radionuclides due to the operation of the Mining-andChemical Combine (MCC), which has a reactor plant producing weapon grade plutonium and a fuelreprocessing plant. The reactor plant was shut down in May 2010, but the fuel-processing plant is still operating. Artificial radionuclides are detected in all ecosystem compartments including biota [1-4]. Migration of artificial radionuclides in freshwater food webs is one of the most important issues addressed by radioecology. Fish fauna is a dietary source connecting the freshwater environment with human population. The transfer of radionuclides from fish to humans depends on their accumulation in certain organs and tissues. There has been no published data on the activity concentration and distribution of artificial radionuclides in bodies of fish species from the Yenisei River yet. In our research we investigated the activity concentration of artificial radionuclides in organs and tissues of five fish species (Thymallus arcticus, Leuciscus leuciscus baicalensis, Lota lota, Esox lucius, Carassius gibelio) sampled from the Yenisei River in the vicinity of the MCC.

\section{MATERIAL AND METHODS}

The fish species: Thymallus arcticus (Pallas) (grayling), Leuciscus leuciscus baicalensis (Dybowski) (dace), Lota lota L. (freshwater cod), Esox lucius L. (Northern pike), and Carassius gibelio (Bloch) (crucian carp) were sampled from the Yenisei River in the vicinity of the MCC from 2007 to 2010. From one (for cod and pike) to 27 fishes (for dace and grayling) were used for one sample. The age of fish was estimated by annual rings on scales or on gill cover (for cod). The age of grayling was 1+ $4+\mathrm{y}$, total length $-201-249 \mathrm{~mm}$, fresh mass $-75-194 \mathrm{~g}$. The age of dace was $42+-4 \mathrm{y}$, total length $-167-189 \mathrm{~mm}$, fresh mass $-42-72 \mathrm{~g}$. The age of pike was $2+-4+\mathrm{y}$, total length $396-509 \mathrm{~mm}$, fresh 
mass $-534-1054 \mathrm{~g}$. The age of cod was $3 \mathrm{y}$, total length $350-550 \mathrm{~mm}$, fresh mass $-621-1318 \mathrm{~g}$. The age of crucian carp was $3+\mathrm{y}$, total length $-150-193 \mathrm{~mm}$, fresh mass $74-129 \mathrm{~g}$.

Fishes were frozen after sampling, and then dissected after slight defrosting. The following parts of the fish body were isolated: bones, muscles, skin with scales, fins with bones of their skeleton; heads, gills, liver, kidney, content of digestive tract, eggs, the sum of other internal organs. In the fish samples of 2007 and August-October 2009, all internal organs (viscera) were analyzed as one sample. Samples of organs and tissues were digested in the mixture of hydrogen peroxide (30\%) and nitric acid (1 M) while heating and concentrated to $100 \mathrm{ml}$ by evaporation. Concentrations of artificial radionuclides in dry biomass of Eulimnogammarus spp. (gammarus) and Apatania crymophila (caddish worm), the main dietary sources of grayling and dace, were also estimated. Activity concentration was measured on a gamma-spectrometer coupled to a hyper-pure-Ge-detector (Canberra, USA).

Transfer factors were estimated as the ratio of activity concentration in dry biomass of gammarus to activity concentration in dry mass of total fish body and muscles.

\section{RESULTS AND DISCUSSION}

Natural isotopes $\left({ }^{7} \mathrm{Be}\right.$ and $\left.{ }^{40} \mathrm{~K}\right)$, artificial neutron-induced isotopes $\left({ }^{46} \mathrm{Sc},{ }^{51} \mathrm{Cr},{ }^{54} \mathrm{Mn},{ }^{58,60} \mathrm{Co},{ }^{59} \mathrm{Fe},{ }^{65} \mathrm{Zn}\right.$, ${ }^{85} \mathrm{Sr}$ ), and fission products $\left({ }^{99} \mathrm{Mo},{ }^{103,106} \mathrm{Ru},{ }^{137} \mathrm{Cs},{ }^{141,144} \mathrm{Ce}\right.$ ) were recorded in fish bodies (Table 1). Most of these isotopes were also recorded in muscles (Table 1). While the muscles comprised from $48 \%$ to $60 \%$ of total mass of the fish body, the major percent (up to $80 \%$ ) of ${ }^{137} \mathrm{Cs}$ and ${ }^{40} \mathrm{~K}$ activity occurred in muscles of fish species, which also contained considerable percentages of ${ }^{60} \mathrm{Co}$ (up to $70 \%$ ) and ${ }^{65} \mathrm{Zn}$ (up to 20\%). The analyzed species of fish fauna of the Yenisei River are typical objects for fishery during the year. Hence, due to accumulation of artificial nuclides in edible parts of fish (including muscles), they can be transferred to local human population with fish used for food.

Artificial radionuclides were also recorded in other analyzed organs and tissues of fish. Several artificial nuclides were also recorded in eggs of grayling and dace: ${ }^{65} \mathrm{Zn}-$ up to $12 \mathrm{~Bq} / \mathrm{kg}$ of fresh mass, ${ }^{137} \mathrm{Cs}$ - up to $2 \mathrm{~Bq} / \mathrm{kg},{ }^{60} \mathrm{Co}-$ up to $1 \mathrm{~Bq} / \mathrm{kg}$. This may cause a decrease in fertility of fish species. The highest activity concentrations of ${ }^{65} \mathrm{Zn},{ }^{60} \mathrm{Co},{ }^{85} \mathrm{Sr},{ }^{106} \mathrm{Ru},{ }^{54} \mathrm{Mn}$ were recorded in kidney. Concentrations of artificial radionuclides were most variable in the digestive tract of fish species during the year.

There were certain differences between activity concentrations of artificial radionuclides in the bodies of nonpredatory (grayling, dace, crucian carp) and predatory (cod, pike) fish species. Among all fish species, the highest activity concentrations of ${ }^{85} \mathrm{Sr}$ and ${ }^{103,106} \mathrm{Ru}$ were recorded in internal organs of cod. ${ }^{85} \mathrm{Sr}$ was not recorded in muscles of predatory fish species.

We revealed seasonal dynamics of artificial radionuclide concentrations in the bodies of grayling and dace. The highest concentrations of ${ }^{65} \mathrm{Zn}$ and ${ }^{137} \mathrm{Cs}$ in muscles were recorded at the end of summer. The concentrations of artificial radionuclides $\left({ }^{60} \mathrm{Co},{ }^{65} \mathrm{Zn},{ }^{85} \mathrm{Sr},{ }^{137} \mathrm{Cs},{ }^{144} \mathrm{Ce}\right)$ in internal organs - liver, kidney, the sum of other internal organs - and in the content of digestive tract increased dramatically in winter and spring as compared to summer and autumn.

This coincided with the change of the diet source of grayling that we revealed from the analysis of the content of food boluses [5]. Hence, the feeding behavior of zoobenthos feeders, dace and grayling, changes fluxes of artificial radionuclides in the Yenisei River during the year. Now that the reactor plant at the MCC is out of operation, the radionuclide deposits in bottom sediments (and flood plain soils) of the Yenisei River will become the mail source of neutron-induced radionuclides like ${ }^{60} \mathrm{Co}$ and ${ }^{65} \mathrm{Zn}$ in the next few years. This can be useful for estimating the bioavailability of radionuclides deposited in bottom sediments.

Of zoobenthos species, we analyzed the activity concentrations of radionuclides in the main diet sources of grayling: caddish worm (Apatania crymophila) and gammarus (mainly Eulimnogammarus viridis). The spectrum and activity concentrations of artificial radionuclides in zoobenthos were higher than in fish species. The transfer factor of several common radionuclides from gammarus to total body 


\begin{tabular}{|c|c|c|c|c|c|c|c|c|c|c|c|c|c|c|c|}
\hline 丞 & 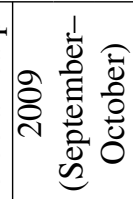 & 1 & 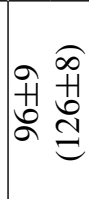 & 1 & & 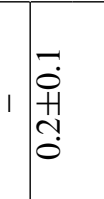 & $\begin{array}{l}0 \\
0 \\
0 \\
H \\
0 \\
0 \\
0\end{array}$ & 1 & 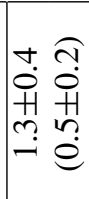 & $\begin{array}{l}n \\
0 \\
1 \\
n \\
0\end{array}$ & 1 & 1 & 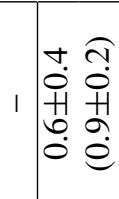 & 1 & 1 \\
\hline & 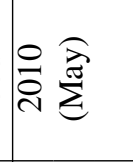 & 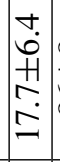 & 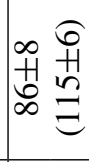 & 1 & 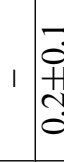 & 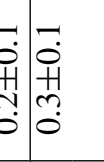 & $\begin{array}{l}\overrightarrow{0} \\
+1 \\
m \\
0\end{array}$ & 1 & $\begin{array}{ll}\forall & \widehat{\imath} \\
0 & 0 \\
+ & +1 \\
m & \infty \\
- & 0\end{array}$ & $\begin{array}{l}m \\
0 \\
+ \\
\text { ñ } \\
-1\end{array}$ & & 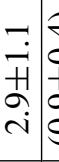 & 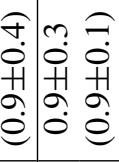 & 1 & 1 \\
\hline & 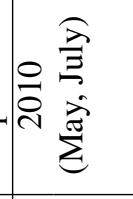 & 1 & 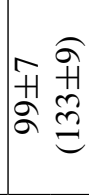 & 1 & $1 \mid \begin{array}{l}\infty \\
0 \\
0 \\
+1 \\
0\end{array}$ & 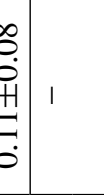 & $\begin{array}{ll}0 & 0 \\
0 & 0 \\
0 & 0 \\
1 & 1 \\
2 & \infty \\
0 & 0 \\
0 & 0\end{array}$ & 1 & 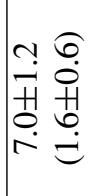 & $\begin{array}{l}\overrightarrow{0} \\
\dot{0} \\
\stackrel{+}{+} \\
\dot{0}\end{array}$ & & $\begin{array}{l}n \\
\vdots \\
+1 \\
n \\
? \\
-\end{array}$ & $\begin{array}{ll}n & \widehat{0} \\
0 & 0 \\
+1 & +1 \\
0 & \frac{1}{0} \\
\dot{\omega} & 0\end{array}$ & 1 & I \\
\hline & 응 $\frac{1}{0}$ 总 & 1 & 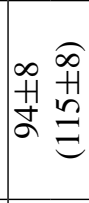 & 1 & 11 & $1 \mid 1$ & 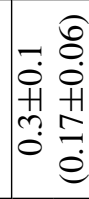 & 1 & 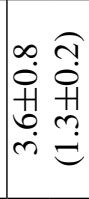 & 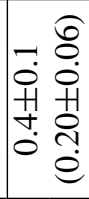 & 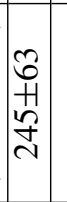 & । & $\begin{array}{ll}0 & 0 \\
0 & 0 \\
+ & +1 \\
n & 0 \\
- & 0\end{array}$ & I & I \\
\hline & 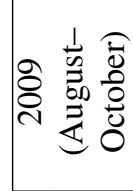 & 1 & 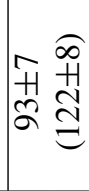 & 1 & । I & 1 & $\begin{array}{l}\overrightarrow{0} \\
\dot{+} \\
\overrightarrow{0} \\
0\end{array}$ & 1 & 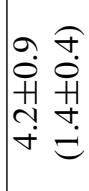 & 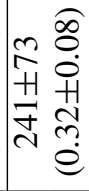 & 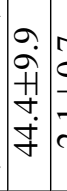 & $\begin{array}{l}r \\
\dot{0} \\
\dot{H} \\
\vec{i}\end{array}$ & 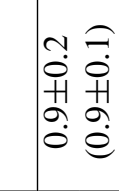 & 1 & | \\
\hline & 总 & 1 & 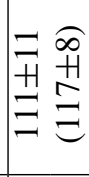 & 1 & 11 & \begin{tabular}{l|l}
1 & 1
\end{tabular} & 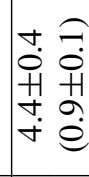 & 1 & 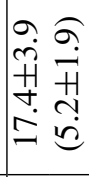 & 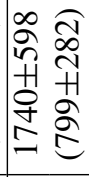 & & 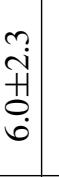 & 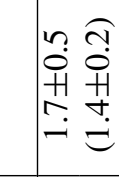 & 1 & $\begin{array}{l}a \\
\vdots \\
+1 \\
m \\
i\end{array}$ \\
\hline & 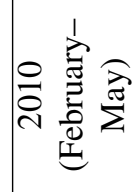 & 1 & 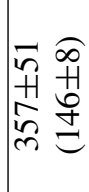 & 1 & 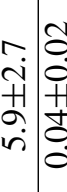 & 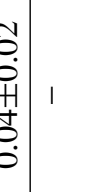 & 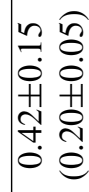 & 1 & 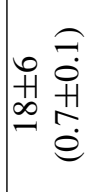 & 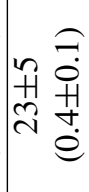 & $\begin{array}{cc}\infty & \\
0 & \\
0 & \\
11 \\
0 \\
i \\
i\end{array}$ & $\begin{array}{l}0 \\
0 \\
0 \\
1 \\
o \\
-\end{array}$ & 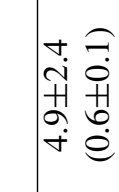 & । & 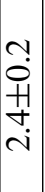 \\
\hline 告 & 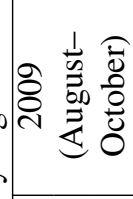 & $\mid \begin{array}{c}1 \\
0 \\
1 \\
n \\
0 \\
0\end{array}$ & 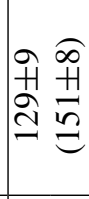 & 1 & $1 \mid \begin{array}{l} \\
0 \\
0 \\
+ \\
0 \\
0 \\
0\end{array}$ & 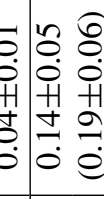 & 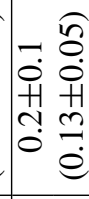 & 1 & 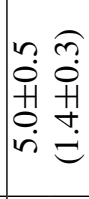 & $\begin{array}{l}1 \\
0 \\
0 \\
+1 \\
0 \\
0 \\
0\end{array}$ & 1 & 1 & 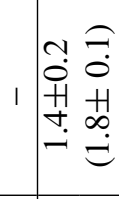 & $\mid \begin{array}{l}\overrightarrow{0} \\
\dot{0} \\
\dot{1} \\
\dot{1} \\
\vdots \\
0 \\
0 \\
0\end{array}$ & $\begin{array}{l}\infty \\
0 \\
0 \\
0 \\
+1 \\
\\
0 \\
0\end{array}$ \\
\hline & 周 & 1 & 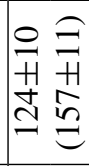 & $\begin{array}{l}n \\
m \\
m \\
m\end{array}$ & 11 & 1 & $\begin{array}{ll}0 & 0 \\
0 & 0 \\
0 & 0 \\
H & +1 \\
& N \\
0 & 0\end{array}$ & 1 & 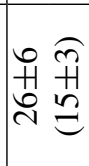 & $\begin{array}{l}n \\
0 \\
01 \\
0 \\
\infty \\
m\end{array}$ & 1 & 1 & 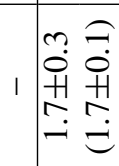 & I & $\begin{array}{l}\vec{z} \\
\overrightarrow{\dot{H}} \\
\vec{i} \\
\dot{i}\end{array}$ \\
\hline & 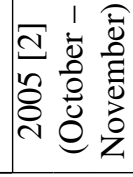 & $=$ & 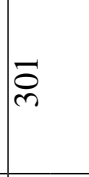 & 1 & 13 & $\overrightarrow{0} 1$ & $\hat{o}$ & $\approx$ & $\cong$ & 11 & 1 & 1 & $1 \hat{i}$ & 1 & 1 \\
\hline & $\begin{array}{l}0 \\
\vdots \\
0 \\
0 \\
0 \\
0 \\
0\end{array}$ & 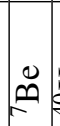 & 亲 & $\begin{array}{l}0 \\
\mathscr{a} \\
\dot{q}\end{array}$ & Ü & $\underbrace{0}_{i}$ & ن & $\mid$ & స్ & $\vec{n}_{\infty}$ & $\sum_{0}^{0}$ & 胥 & $0_{0}^{\infty}$ & $\underset{\Xi}{0}$ & \\
\hline
\end{tabular}


Table 2. Transfer factors of radionuclides from gammarus to grayling total body and muscles in September and October 2009.

\begin{tabular}{|l|c|c|c|c|}
\hline \multirow{2}{*}{ Isotope } & \multicolumn{4}{|c|}{ Transfer factor } \\
\cline { 2 - 5 } & \multicolumn{2}{|c|}{ Total body } & \multicolumn{2}{c|}{ Muscles } \\
\cline { 2 - 5 } & September & October & September & October \\
\hline${ }^{40} \mathrm{~K}$ & 1.23 & 1.35 & 1.38 & 1.32 \\
\hline${ }^{60} \mathrm{Co}$ & 0.002 & 0.04 & - & 0.01 \\
\hline${ }^{65} \mathrm{Zn}$ & 0.16 & 0.17 & 0.05 & 0.05 \\
\hline${ }^{85} \mathrm{Sr}$ & 0.09 & 0.01 & - & - \\
\hline${ }^{137} \mathrm{Cs}$ & 0.16 & 0.14 & 0.17 & 0.12 \\
\hline
\end{tabular}

and muscles of grayling was estimated for autumn samples of 2009, when gammarus was the main diet source for grayling (Table 2). The transfer factor was above one only for ${ }^{40} \mathrm{~K}$, the transfer factors of artificial nuclides were much lower (Table 2). Among artificial radionuclides the transfer of ${ }^{137} \mathrm{Cs}$ was most effective.

\section{CONCLUSIONS}

Gamma-spectrometric analysis of five species of fish from the Yenisei River in the vicinity of the Mining-and-Chemical Combine revealed artificial neutron induced radioisotopes and fission products in their organs and tissues, including the main edible parts of these fish species (muscles and eggs). Fission product radionuclides originating from the fuel-processing plant (including ${ }^{99} \mathrm{Mo}$ and ${ }^{103,106} \mathrm{Ru}$ ) were also registered. The major percent (up to $80 \%$ ) of ${ }^{137} \mathrm{Cs}$ and ${ }^{40} \mathrm{~K}$ activity occurred in muscles of fish species, which also contained considerable percentages of ${ }^{60} \mathrm{Co}$ (up to $70 \%$ ) and ${ }^{65} \mathrm{Zn}$ (up to $20 \%$ ). Hence, the probability of the diet transfer of artificial radionuclides to local human population increases.

Seasonal changes were recorded in artificial radionuclide intake by zoobenthos-feeding fish species (grayling and dace). The dramatic increase in radionuclide intake by grayling coincided with the change of diet source. Hence, the feeding behavior can change the fluxes of artificial radionuclides in the Yenisei River.

The most effective diet transfer of a radionuclide from gammarus to grayling (muscles and total body) was recorded for ${ }^{40} \mathrm{~K}$ (1.3) and much less effective for artificial nuclides.

\section{References}

[1] Bolsunovsky A. and Bondareva L., J Alloy Compd. 444-445 (2007) 495-499.

[2] Pan'kov Ye.V., Bolsunovsky A.Ya., Pimenov A.V. and Sukovaty A.G., "Concentration of radionuclides and dose rates of some species of ichthyophauna of the Yenisei River", Heavy metals and radionuclides in the environment, V. 1, IV international conference, Semipalatinsk, Kazakhstan, 2006, E.B. Sydykov, M.S. Panin (Semipalatinsk State Pedagogical institute, Semipalatinsk, Kazakstan, 2006) pp. 356-360. (In Russian)

[3] Zotina T.A. 2009. Radiation biology. Radioecology. 49 (6) (2009) 729-737. (In Russian)

[4] Zotina T.A., Trofimova E.A., Kaglyan A.Ye., Bolsunovsky A.Ya. and Gudkov D.I. Problems of biogeochemistry and geochemical ecology 1 (2010) 91-94. (In Russian)

[5] Zuev I.V., Semenova E.M., Shulepina S.P., Reznik K.A., Trofimova E.A., Shadrin E.A., Zotina T.A. J Siberian Fed Uni 4 (2) (2011) (in press) 